University of Warwick institutional repository: http://go.warwick.ac.uk/wrap This paper is made available online in accordance with publisher policies. Please scroll down to view the document itself. Please refer to the repository record for this item and our policy information available from the repository home page for further information.

To see the final version of this paper please visit the publisher's website. Access to the published version may require a subscription.

Author(s): Christopher W. Hughes

Article Title: Why Japan Could Revise Its Constitution and What It Would Mean for Japanese Security Policy

Year of publication: 2006

Link to published version:

http://dx.doi.org/10.1016/j.orbis.2006.07.011

Publisher statement: none 


\section{Why Japan Could Revise Its Constitution and What It Would Mean for Japanese Security Policy}

\section{by Christopher W. Hughes}

Christopher W. Hughes (c.w.hughes@warwick.ac.uk) is Senior Research Fellow at the Centre for the Study of Globalisation and Regionalisation, University of Warwick, UK. This article is based on his presentation at a conference on Constitutional Change and Foreign Policy in East Asia held by FPRI's Center for East Asian Studies in Philadelphia on March 20, 2006.

Abstract: This article seeks to make sense of the policy debate on constitutional revision underway in Japan, to consider what international and domestic factors are driving the debate forward, to assess the range of proposals currently on the table, and to gange the likelihood of actual constitutional change. Additionally, it considers how various forms of constitutional revision, if actually implemented, might affect Japan's military doctrines and capabilities; the extent of its alliance cooperation with the United States; its devotion of military capabilities to UN operations; and the repercussions for Japan's regional relations in East Asia.

Since its promulgation in 1946, Japan's constitution, and in particular its preamble and the article 9 "peace clause," have occupied central positions in determining the direction of Japanese security policy. The constitution is the origin of a range of prohibitions and anti-militaristic principles that constrain Japan's use of military force for national security ends, limiting the military to defending only the state's own territory. It also creates significant barriers to cooperation with the United States and with the wider international community. Although Japan's constitution is not unique in its pacifistic sentiments, it is arguably unique among developed great powers for its emphasis on anti-militaristic and pacifist strictures. ${ }^{1}$

The constitution has long been the battleground between policymakers both within and outside Japan who wish to push Japan toward a more proactive, or "normal," international military role and those opposed to this, who are concerned about the possible recrudescence of militarism. For the Social Democratic Party (SDPJ) and other opposition parties for most of the postwar years, preserving the constitution (goken) has been of paramount importance. Other policymakers, including what might be termed the mainstream, conservative pragmatists within the governing Liberal Democratic Party (LDP), have balked at the restrictions of the "U.S.-imposed" constitution but have seen some advantage in it as a means to argue

${ }^{1}$ For a comparison of article 9 with other states' constitutions, see "Ima, Kokkai Giiin wa Donna Giron o Shite Iru Ka?,” Ekonomisuto Rimji Zokan, July 2004, p. 14. 


\section{HUGHES}

for "credible incapacity" and to delimit Japan's military commitments to the United States. Hence, they prefer incremental reinterpretation (kaishaku kaiken) of the constitution to nudge Japan toward a more proactive security role. ${ }^{2}$ For a range of other conservatives from the LDP, straight constitutional revision (kaiken) has been an essential long-term goal. The conservative revisionists share the conservative pragmatists' dissatisfaction with the constitution, but perceive constitutional change as a prerequisite for a variety of reasons, including the desire to finally bring to a close the "postwar period" and constraints on Japan's sovereignty and national dignity; to enhance Japan's capacity to work with all the usual prerogatives of a sovereign state with the UN and the United States in military security; and to produce clearer constitutional guidelines on the use of force.

\section{The Latest Debate}

The latest debate on constitutional revision originated in the early 1990s but intensified beginning in 2000, and especially since Junichiro Koizumi became prime minister in 2001 (which post he leaves in 2006). This current debate is more extensive and has gained more decisive momentum than preceding instances, thus hinting at the real possibility of the constitution's revision for the first time in its sixty-year history. This momentum is generated by fundamental shifts in Japan's international security environment and its ties with the United States, and also by seismic shifts in the structure of domestic politics. The LDP revisionists are now increasingly joined in their efforts by elements of the opposition Democratic Party of Japan (DPJ). The proposed changes cover the preamble, article 9, and the lifting of the prohibition on exercising the right of collective self-defense. All of the major parties have constitutional research committees drafting proposed revisions: the LDP released its draft revision in November 2005 and the opposition DPJ is set to release its own version in 2006. The House of Representatives and House of Councillors of the Japanese National Diet have conducted research committees on the matter since 2000, releasing separate reports in 2005; and the LDP and DPJ, after attempts at submitting joint legislation, then submitted individually in May 2006 Diet bills to put in place the necessary national referendum procedures to enable constitutional revision.

The most cautious of the proposals for revision would recognize the current de facto incremental expansion of Japan's individual military capabilities and U.S.-Japan alliance cooperation, and non-combat support for UN peacekeeping operations; the more radical would provide a new role for Japan to engage in full combat operations in U.S. and UN-led multinational coalitions. The proposals have raised expectations among U.S. policymakers who are keen to see a strengthened alliance, but also heightened apprehensions and criticism of Japan's evolving defense posture among East Asian states such as South Korea and China.

2 J. Patrick Boyd and Richard J. Samuels, Nine Lives? The Politics of Constitutional Reform in Japan, Policy Studies 19 (Washington: East-West Center, 2005), pp. 17-19. 


\section{The Preamble, Article 9, and collective self-defense}

The constitution's preamble states Japan's ideals with regard to security:

We, the Japanese people, desire peace for all time and are deeply conscious of the high ideals controlling human relationship, and we have determined to preserve our security and existence, trusting in the justice and faith of the peace-loving peoples of the world. We desire to occupy an honored place in an international society striving for the preservation of peace, and the banishment of tyranny and slavery, oppression and intolerance for all time from the earth. We recognize that all peoples of the world have the right to live in peace, free from fear and want.

Chapter 2 of article 9 of the constitution, "The Renunciation of War," reads as follows:

Aspiring sincerely to an international peace based on justice and order, the Japanese people forever renounce war as a sovereign right of the nation and the threat or use of force as means of settling international disputes.

In order to accomplish the aim of the preceding paragraph, land, sea, and air forces, as well as other war potential, will never be maintained. The right of belligerency of the state will not be recognized. [emphasis added]

Original drafts of article 9 drawn up by the Supreme Commander for the Allied Powers were intended to prohibit Japan not only from engaging in offensive warfare, but also from the use of force for national self-defense and from maintaining any military establishment. However, the final drafts left open the possibility of modest rearmament for Japan to preserve its own security. ${ }^{3}$ Amendments to article 9 made in the Diet during the passage of the constitution in 1946, introduced by Hitoshi Ashida, led to the insertion of the phrase, "in order to accomplish the aim of the preceding paragraph." This opened the way for an interpretation of the constitution allowing Japan to maintain military forces for other purposes as long as these were not designed as a means of aggressive war and settling international disputes.

In his first term as prime minister (1946-47), Shigeru Yoshida, overseeing the final passage of the constitution and seeking to end the Occupation by establishing Japan's anti-militarist credentials, offered an original interpretation of article 9 as prohibiting both offensive war and the right of self-defense. But in his second premiership (1948-54), he began to back away from this interpretation, looking to conclude a security pact with the United States by offering it the use of Japanese bases. Now the government stated that renouncing war did not mean

${ }^{3}$ John Dower, Embracing Defeat: Japan in the Aftermath of World War II (London: Penguin Books, 1999), pp. 360-61, 368, 394-96. 


\section{HUGHES}

abandoning the right of self-defense. ${ }^{4}$ Since the 1950s Tokyo has interpreted article 9 as permitting Japan, in line with its position as a sovereign state under the UN Charter, to exercise the right of individual national self-defense and to maintain the Japan Self-Defense Forces (JSDF) for this purpose.

Following this interpretation, the government has pursued an "exclusively defense-oriented" policy and elaborated a number of other constitutional prohibitions on the exercise of military power, such as restricting the JSDF's military capacity to the minimum necessary for self-defense; and rejecting most overseas JSDF deployments as exceeding the levels of force necessary for self-defense.

Most importantly, the government has banned exercising the right of collective self-defense. As a sovereign state, Japan possesses under article 51 of the UN Charter the inherent right of collective self-defense. Since 1954, though, Tokyo has taken the position that exercising this right would exceed the minimum necessary force for the purposes of self-defense and be unconstitutional. Japan does not regard JSDF support for military forces of other states as unconstitutional if these actions do not involve military combat, but simply logistical support such as transport, supply, maintenance, medical services, guard duty, and communications. Japanese policymakers contemplated exercising the right of collective self-defense during the early stages of the Cold War as a means to create a more equal relationship with the United States in security, but did not for fear of entanglement in overseas military operations. ${ }^{5}$

Japan's exercise of military force has been governed also by a range of antimilitaristic principles, many derived from the preamble and article 9 of the constitution, although they are not constitutionally binding. The most prominent of these are Japan's pledge not to become a military great power; its Three NonNuclear Principles of 1967 (to not produce, possess, or introduce nuclear weapons); restrictions on the exports of arms and military technology introduced in 1967 and 1976; and the 1 percent GNP limit on defense expenditure introduced in 1976.

In fact, Tokyo has demonstrated a remarkable capacity to reinterpret the constitution in order to stretch Japan's military security posture. Prime Minister Yoshida initiated this approach through the reversal of the interpretation on the ban on individual self-defense in the 1950s. The ban on exercising the right of collective self-defense was an innovation of Yoshida and the powerful bureaucrats of the Cabinet Legislation Bureau (CLB), who sought a means to legitimize establishing the JSDF for purposes of self-defense but barring its deployment on potentially dangerous missions overseas. ${ }^{6}$

Also, during the later stages of the Cold War, Tokyo took its first steps to further Japan's integration into U.S. regional and global military strategy, such as

4 Tetsuo Maeda and Shigeaki Iijima, eds., Kokkai Shingi Kara Boeiron o Yomidoku (Tokyo: Sanseido, 2003), pp. 15-18.

${ }^{5}$ Boyd and Samuels, Nine Lives?, p. 23.

${ }^{6}$ Richard J. Samuels, Politics, Security Policy and Japan's Cabinet Legislation Bureau: Who Elected These Guys, Anyway? JPRI Working Paper, March 2004, at www.jpri.org. 
assuming responsibility under the 1978 Guidelines for Japan-U.S. Defense Cooperation to protect sea lines of communication up to 1,000 nautical miles from Japan. ${ }^{7}$ For many these appeared as de facto acts of collective self-defense, but because Japan-U.S. security cooperation was mainly concentrated around Japan itself and designed to counter a mutual Soviet threat, Tokyo could justify these actions under the right of individual self-defense. Tokyo in this period also seriously eroded many of its own anti-militaristic principles. It is believed to have allowed the transit through Japanese ports of U.S. nuclear weapons; it removed the ban on the export of weapons technology exclusively for the United States; and it effectively breached the 1 percent limit on defense spending in 1986, although it has stayed at around 1 percent since then.

Hence, Japan's policymakers have shown great ingenuity in reinterpreting the constitution around the margins in order to build up significant military capabilities and to strengthen alliance cooperation. Nevertheless, by the early 1990s it was becoming increasingly clear to Japan's policymakers that they were facing a set of international strategic and domestic political circumstances that had them bumping up against the limits of constitutional reinterpretation; they needed to consider moves towards open revision.

\section{Drivers of the Revision Debate}

\section{Global and regional security crises}

Since the end of the Cold War Japan has faced cycles of global and regional insecurity that its policymakers have perceived as demanding a new set of responses and an enhanced role for the JSDF. Globally, the 1991 Gulf War presented Japan for the first time with demands to make a "human contribution" in support of the U.S.led war effort by deploying the JSDF to the Gulf as part of a multinational coalition. Since 9/11, Japan has once again been under growing pressure to deploy the JSDF overseas in support of the U.S.-led "war on terror". Regionally, Japan has experienced the twin crises of the first North Korean nuclear crisis and the Taiwan Straits crisis between 1993 and 1996, a second North Korean nuclear crisis from 2000 onwards, as well as the rise of China. For Japanese policymakers the lesson drawn from these crises has been the need to upgrade the U.S.-Japan alliance in order to strengthen its deterrence functions to deal with regional contingencies.

\section{Domestic political realignments}

Japanese politics began a significant depolarization over security issues following the collapse of the LDP-dominated, 1955 political system, marked by the party's temporary loss of power in 1993-94 and then its reentry into government

7 Glenn D. Hook and Gavan McCormack, Japan's Contested Constitution: Documents and Analysis (London: Routledge, 2001), p. 17. 


\section{HUGHES}

from 1994 through a series of coalitions, the most lasting of which is with the Komeito (Clean Government Party) from 1999 to the present. The collapse of the 1955 system reduced effective opposition from the Left to constitutional revision, signified especially by the SDPJ's loss of its position as the main opposition party. The SDPJ did enter into an ill-fated coalition with the LDP from 1994-96, but at the price of abandoning its traditional opposition to the constitutionality of the JSDF and the U.S.-Japan security treaty. The represented not only the SDPJ's selfabdication as one of the principal political checks upon Japanese remilitarization, but also its disintegration as a force in the Diet, with its strength reduced by 2006 to eleven members. The SDPJ has found itself successively punished by an electorate that felt the party had sold out on its anti-militaristic principles or was no longer relevant in a changing security environment.

The SDPJ's position as the main opposition party has been assumed by the DPJ, formed in 1996 by splinter groups from the SDPJ and smaller parties that had originally split from the LDP. The DPJ is broadly centrist in orientation and does contain an important rump of SDPJ and social progressive members. But the LDP heritage of many of its members, combined with the rise of a group of younger conservatives, means that it also has a propensity to converge with the LDP on issues of security policy and the need to consider constitutional revision.

The collapse of the 1955 system induced a similar depolarization process on the Right, within the LDP itself. Previous constitutional-revision attempts in the late 1950s and early 1960s arguably foundered not so much on the socialist opposition, but on internal divisions between the LDP's pragmatist and revisionist camps. ${ }^{8}$ Since the late 1990s, though, the pragmatists became progressively weaker and the revisionists, in the guise of Prime Minister Koizumi and his Yoshiro Mori faction associates, took effective control of the party. Koizumi contributed to the implosion of the formerly dominant Ryutaro Hashimoto faction and the retreat from the political scene of more "dovish" figures such as the former Chief Cabinet Secretary Hiromu Nonaka. Koizumi also ensured the marginalization of Koichi Kato, another former chief cabinet secretary and former leader of the Kiichi Miyazawa faction, the principal pragmatist faction tracing its lineage back to Prime Minister Yoshida. ${ }^{9}$ The consequence is that the governing party and government's policy direction are increasingly dominated by revisionists such as Koizumi himself; Shinzo Abe, the current chief cabinet secretary and the grandson of Nobusuke Kishi, the architect of revision attempts in the 1950s and 1960s; Yasuo Fukuda, a former chief cabinet secretary and son of the revisionist Prime Minister Takeo Fukuda; Taro Aso, the current foreign minister and grandson of Yoshida; and Taku Yamazaki, a member of the arch-revisionist faction of former Prime Minister Yasuhiro Nakasone.

\section{The Limits of Constitutional Reinterpretation}

8 Robert Ward, "The Commission on the Constitution," The Journal of Asian Studies, vol. 24, no. 3, 1965 , p. 422.

${ }^{9}$ Boyd and Samuels, Nine Lives?, p. 31. 
Japan's government and opposition politicians are increasingly converging in their willingness to respond to new security challenges by adjusting constitutional restraints. Many of them feel that Tokyo's response thus far to existing challenges, and especially its tradition of stretching constitutional interpretations, has been inadequate. The government attempted to respond to the 1991 Gulf War by submitting to the Diet a UN bill that would have enabled the deployment of a UN Peace Cooperation Corps composed of volunteer JSDF personnel to engage in noncombat operations, but stiff opposition from the SDPJ and poor preparation scuttled the bill. The government was then obliged to underwrite the war financially with a contribution of $\$ 13$ billion, derided by much of the international community as "checkbook diplomacy."

In the run-up to and after that war, the LDP also considered other means to stretch the constitution to enable JSDF deployment. Ichiro Ozawa, then the LDP secretary-general, later leader of the Liberal Party, and now leader of the DPJ, has asserted all along that the JSDF could have been deployed to the Gulf and to similar contingencies for combat operations in line with the concept of "international security" or "collective security," without the need for constitutional revision. ${ }^{10}$ Ozawa's concept of collective security contrasts with collective self-defense: the latter is an inherent right under article 51 of the UN Charter, whereas the former derives from earlier articles of chapter 7 (especially article 43) which stress the exercise of force only if sanctioned by the UN and if for the purposes of collective retaliation by UN members against aggression. ${ }^{11}$ Ozawa has argued that the constitution's preamble, which obliges Japan to cooperate with the international community for the purposes of international stability, means that Japan can participate in any form of UN-sanctioned and UN-centered multilateral military activity without violating article $9 .{ }^{12}$

Japan was eventually forced to settle for a minimal "human contribution" in the form of the deployment of six Maritime Self-Defense Force minesweepers to the Gulf in April 1991, after the cessation of hostilities, on the grounds that clearing mines from sea lanes in peace time did not constitute the use of force. Ozawa established an LDP Special Study Group on Japan's Role in International Security, ${ }^{13}$ but its findings were largely marginalized as the government shifted its focus to passing the International Peace Cooperation Law of June 1992, enabling the

10 Yoshitaka Sasaki, Umi o Wataru Jietai (Tokyo: Iwanami Shinsho, 1992), pp. 13-17; Nobumasa Tanaka, Kempo Kyujo no Sengoshi (Tokyo: Iwanami Shinsho, 2005), p. 135.

11 Tomohito Shinoda, "Taigai Seisaku Kettei no Akuta Toshite no Ozawa Ichiro," in Kohei Hashimoto, ed., Nihon Gaiko Seisaku Kettei Yoin (Tokyo: PHP Kenkyujo, 1999), p. 41.

12 Akihiko Tanaka, "The Domestic Context: Japanese Politics and UN Peacekeeping," in Selig S. Harrison and Masashi Nishihara, eds., UN Peacekeeping: Japanese and American Perspectives (New York: Carnegie Endowment for International Peace, 1995), pp. 93-94.

13 Shigenobu Tamura, Kempo to Anzen Hosho (Tokyo: Nansosha, 1993), pp. 101-135. 


\section{HUGHES}

dispatch of the JSDF on limited non-combat UN peacekeeping operations, again in conformity with the strictures of article 9 .

In responding to post-9/11 security threats, Japan has again been forced to stretch the constitution, again with mixed results. In October 2001 the Diet passed the Antiterrorism Special Measures Law, to permit deploying the JSDF to the Indian Ocean to provide non-combat support to U.S.-led operations in Afghanistan. Unlike the United States' NATO allies, Japan could not invoke the right of collective selfdefense to justify support for the campaign. It could have followed the United States in relying principally on the right of individual self-defense, but this might have mandated the constitutional use of force and an open-ended combat mission.

Instead, it preferred non-combat JSDF deployment, which invokes neither individual nor collective self-defense, but is predicated on UN resolutions. Japan has stressed UN resolutions that identify the $9 / 11$ attacks on the United States as a threat to international peace and call on all UN members to combat terrorism. Japan linked this UN legitimacy to its own constitution to legitimize JSDF deployment by switching emphasis from article 9 to the preamble, the latter stating Japan's obligation to work with international society for the preservation of peace. Japan thus used the preamble to argue that it should support the UN, as international society's highest representative, and counter terrorism. It bridged UN resolutions, its constitution, and support for the United States by stressing that its support was not just for the United States, but for the whole international community. Japanese policymakers used a similar method to justify the passage of the Iraqi Reconstruction Law in July 2003, which has enabled JSDF deployment to Iraq on non-combat reconstruction missions since early 2004. Tokyo predicated the law on extant, if rather weak, UN resolutions; and in arguing for the constitutionality of JSDF dispatch in December 2003, President Koizumi chose to read out in support the preamble rather than article 9 .

In utilizing these formulas for Indian Ocean and Iraq deployments, Tokyo has actually arrived back at a de facto type of collective security, close to Ozawa's original conception. Policymakers managed to achieve many of their basic objectives through these constitutional reinterpretations, the Antiterrorism Special Measures Law, and the Iraqi Reconstruction Law. Japan was able to project a visible military presence in support of the United States, and in the case of the Indian Ocean to effect relatively rapid JSDF deployment. These first-ever JSDF deployments during ongoing conflicts expanded the geographical range of deployment and represented new mandates for the use of weapons to defend not only JSDF personnel but also U.S. servicemen and refugees. In contrast to its experience in the Gulf War, Japan has received important credit from Washington for these measures.

Moreover, by meticulously maintaining its ban on collective self-defense, Japan was able to continue to hedge around the degree of military support offered to the United States. Japan pledged only non-combat support and deployed the JSDF to effectively non-combat zones. Its legitimization of JSDF dispatch based on existing UN resolutions provided it with a potential opt-out clause from conflicts that it viewed as insufficiently supported by the UN. In addition, the use of separate 
laws for each deployment erected firewalls around each mission, enabling the government to simultaneously push forward, but also limit on a case-by-case basis, the support that it provides to the United States, and to potentially distinguish the support Japan provides to the United States in the "war on terror" from the support it offers under the bilateral security treaty.

Nevertheless, policymakers see serious drawbacks to this constitutional reinterpretation approach. The attempt to circumvent the ban on exercising the right of collective self-defense through the Antiterrorism Special Measures Law and Iraqi Reconstruction Law is seen to have imposed cumbersome operational restrictions on JSDF cooperation with other states to respond to terrorism. Furthermore, the de facto collective security option, although opening up the possibility of a hard-edged military combat role for the JSDF, is not one that can be explicitly explored as the principal basis of Japan's international security role, because it is UN-centered. Japan could continue to exploit UN legitimization to provide support for the United States, but further pushing the linkages between the UN and its own security policy might set up tensions with Washington's disinclination to allow the UN to constrain its own and its allies' actions. Hence, in cases where no UN resolutions exist, Japan's collective-security option might lead to inaction in support of its ally. Moreover, the government's approach to JSDF deployment in the "war on terror" has drawn criticism from some both within the LDP and in the opposition parties who see it as stretching the constitution and leading Japan into potentially hazardous conflict situations in support of the United States.

Likewise, Japan's experience of regional security crises in the years between the Gulf War and 9/11 further drove home for its policymakers the growing inadequacies of constitutional interpretation alone as a means to respond to existing threats. Japan failed to respond to U.S. requests for logistical support in the event of a conflict during the run-up to the first North Korea nuclear crisis, its hesitancy the product of long-held anxiety over entanglement in a U.S.-led conflict on the Korean Peninsula, the prohibition on collective self-defense, and the consequent lack of planning under the 1978 Japan-U.S. Defense Guidelines for regional contingencies. This exposed the essential inoperability and emptiness of the alliance. In the wake of the crisis, Japanese policymakers sought to shore up the alliance by revising the Guidelines, a response once again involving skillful constitutional interpretation. By revising the Defense Guidelines in 1997 and then in May 1999 passing the Regional Contingency Law, Tokyo was able to fill in the alliance's operability gaps, specifying for the first time the range of non-combat, rear-area logistical support it could provide to the United States under article 6 of the security treaty in the event of regional contingencies.

Tokyo countered accusations of the potential exercise of collective selfdefense in support of the United States with constitutional hair-splitting and linguistic artifices. For instance, it insisted that it was possible even in the thick of a regional military conflict to fix a line between combat zones involving U.S. deployments and non-combat zones for JSDF logistical deployments in support of 


\section{HUGHES}

the US, and thus that there was no risk of the JSDF becoming sucked into the exercise of collective self-defense.

Stretching its constitutional interpretations has enabled Tokyo to expand the range of non-combat support that it can offer to the United States, while retaining its constitutional prohibition as a hedge against unnecessary entanglement in regional conflicts, especially over Taiwan. Nonetheless, its tactics have encountered criticisms similar to those ranged against JSDF deployment to the Indian Ocean and Afghanistan. On the one hand, the Regional Contingency Law is seen to have created operational guidelines for the JSDF that may be overly restrictive in actual combat situations, hampering effective U.S.-Japan alliance cooperation and jeopardizing Japan's ability to defend itself against threats involving North Korea and China. On the other hand, Tokyo is again seen to have subverted the constitution in the name of prioritizing alliance cooperation with the United States and in order to bypass open democratic debate concerning the country's strategic interests in the region and vis-à-vis the United States.

Finally, Japanese policymakers have to consider escalating demands from their U.S. counterparts for expanded alliance cooperation on a regional and now global scale. The clear intention of U.S. military strategy under the Bush administration has been to activate U.S. regional bases and alliances for global security functions. ${ }^{14}$ Japan has in part responded to these expectations through engaging in the bilateral Defense Policy Review Initiative since 2004 and discussing the realignment of U.S. bases in Japan and enhanced bilateral cooperation. In line with that Initiative, Tokyo has agreed to relocate the headquarters of U.S. Army I Corps, a rapid-reaction force for deployment in East Asia and beyond, to Camp Zama in Kanagawa Prefecture and to locate its own newly established rapid-reaction Ground Self-Defense Force alongside it. In addition, as a step toward introducing a ballistic missile defense system, Tokyo has agreed to establish a joint U.S.-Japan air defense command base at Yokota in order to share sensor information. These military alignments place significant pressure on Japan's existing prohibition on collective self-defense. Indeed, Japan's deployment of a BMD system may be the military change that finally forces policymakers to breach the ban on exercising the right of collective self-defense.

In acquiring BMD, Japan will acquire a weapons system fully interoperable with U.S. assets, perhaps leading to enhanced demands for Japan to deploy these in multinational coalitions outside its own territory and in combat situations. Moreover, in order to operate BMD effectively, it will need to rely on U.S. infrared earlywarning satellite information and to construct an architecture allowing for the flow of information between U.S. and Japanese command-and-control systems. This can only create further pressure for constitutional revision and lifting the ban on collective self-defence.

14 See its National Security Strategy and National Defense Strategy of 2005, the Quadrennial Defense Reviews of 2001 and 2006, and the ongoing Global Posture Review. 
Tokyo is unlikely to receive from Washington relief from the pressure to reconsider its constitutional prohibitions. Since Richard Nixon's infamous reference to article 9 as a "mistake" when visiting Tokyo as vice president in 1953, U.S. policymakers have exerted varying degrees of indirect pressure on Japanese thinking over its constitution. 15 The Armitage Report of 2000 stated that "Japan's prohibition against collective self-defense is a constraint on alliance cooperation. Lifting this prohibition would allow for closer and more efficient security cooperation,"16 and in 2004 Secretary of State Colin Powell stated that article 9 was a potential obstacle for Japan's bid to obtain a permanent UN Security Council seat. ${ }^{17}$

In the words of one LDP policymaker at the time of the Antiterrorism Law debate, Masazuki Gotoda, the constitution has been stretched like an "elastic band" to breaking point. ${ }^{18}$ Many Japanese policymakers believe that the time has now arrived for a full debate on constitutional revision in order to put Japan's security in order, be it to free up or impose new restrictions on JSDF activities.

\section{Proposals for Japanese Constitutional Revision}

Japanese political party proposals for constitutional revision are diverse, but as will be indicated below, have coalesced around three key issues and two potential processes to effect revision.

\section{$L D P$}

The LDP has long advocated constitutional revision as part of its platform, and its interest in actually implementing revision gathered momentum under Prime Minister Koizumi. In 2004, its Policy Affairs Research Council (PARC) issued a report recommending amendment of article 9 to recognize the JSDF as a national armed force responsible for national territorial defense and the support of international security and to assert clearly the rights of both individual and collective self-defense. In addition, it recommended passing a Basic Law for National Defense and general law governing international peace cooperation activities that would replace the practice of passing ad hoc legislation to cover individual JSDF missions, to enable Japan to respond more readily to international contingencies. ${ }^{19}$ PARC's Research Commission on the Constitution in June 2004 produced its own initial debating points on constitutional revision, including lifting the ban on collective

${ }^{15}$ Hook and McCormack, Japan's Contested Constitution, p. 14.

16 Institute for National Strategic Studies, The United States and Japan: Advancing Toward a Mature Partnership, INSS Special Report (Washington, D.C.: National Defense University, 2000).

17 “Article 9 a UNSC Bid Hurdle: Powell," Japan Times Online, Aug 14, 2004.

18 Asabi Shimbun Yukan, Oct. 5, 2001, p. 17.

19 Defense Policy Studies Subcommittee, National Defense Division, Policy Research Council, Liberal Democratic Party, Recommendations on Japan's New Defense Policy-Towards a Safer and More Secure Japan and the World, March 30, 2004, pp. 8-9, at www.jimin.jp. 


\section{HUGHES}

self-defense. ${ }^{20}$ In January 2005 the party's new Constitution Drafting Committee assumed responsibility for taking the process forward. It published its final draft revision in November, to coincide with the fiftieth anniversary of the LDP's founding. The committee was largely dominated by the party's revisionist sections, with Koizumi ally and faction boss Mori acting as chairman and Fukuda and Nakasone chairing the subcommittees on article 9 and the preamble, respectively.

The revisionist stamp on these early proposals was seen in, for instance, stating the duty of citizens to defend the country. ${ }^{21}$ However, mindful of the need to placate the party's pragmatists and coalition partner Komeito, the committee took care to finesse the language. Most controversial within the LDP was the issue of the form and extent of the lifting of the collective self-defense prohibition. ${ }^{22}$ Aso, for instance, prefers straight constitutional revision to incorporate this right, while Abe prefers a change of the CLB interpretation. ${ }^{23}$ Others such as Yamasaki prefer a more limited form of collective self-defense exercised only within Japan's own region or in cases of attack upon the United States; while some prominent pragmatists, such as Finance Minister Sadakazu Tanigaki, a member of the Kato faction, remain cautious on the whole matter. ${ }^{24}$

The LDP's November 2005 draft plan identified three key points upon which intra-party consensus can be reached. Chapter 2 would be renamed from "renunciation of war" to "security"; its first paragraph and its pacifist principles would be retained. The sentence Ashida inserted, beginning "in order to," is removed, and major changes are made to the second paragraph. First, the JSDF's existence is recognized and its name changed to Self-Defense Military (Jieigun). Second, the military is specifically charged with international cooperation for the preservation of peace and security. This change is reinforced by the revised preamble, which pledges the Japanese people to cooperate for the preservation of international peace. ${ }^{25}$ The collective self-defense issue is not addressed through constitutional revision; rather, the LDP plans to submit to the Diet a separate Basic National Security Law specifying the right and particular conditions for the exercise of collective self-defense. ${ }^{26}$

The LDP appears to believe that it can effect this change because of the subtle modification in the status of the JSDF in its revised Article 9. It can argue that by establishing in the revised Constitution the principle of Japan's possession of a military (gun) with international security responsibilities, rather than just a force designed for individual self-defense per se, and by setting this alongside the established principle of Japan's inherent possession of the right of collective selfdefense, then it is only natural for Japan in the bill for the Basic National Security

\footnotetext{
20 "Futsu no Kuni Meikaku Ni," Nibon Keizai Sbimbun, June 5, 2004, p. 2.

${ }^{21}$ Boyd and Samuels, Nine Lives?, p. 56.

22 "Jimin, Minshu Mizo Umarazu," Asahi Shimbun, March 30, 2005, p. 4.

23 "Kawaru Kempo Rongi," Asabi Shimbun, May 3, 2006, p. 11.

24 "Kagi Nigiru Posuto Koizumi Sedai," Asabi Sbimbun, June 2005, p. 3.

25 Jiyu Minshuto, Shinkempo Hoan, pp. 2, 4-5, at www.jimin.jp.

26 “Jimin Shinkempo Kiso Yoko," Asabi Shimbun, April 5, 2005.
} 
Law to breach its self-imposed ban to exercise this right and to use its military forces to support its U.S. ally and the international community. ${ }^{27}$ LDP policymakers also draw confidence that this legislative and reinterpretative package can be pushed through because the drafting of the bill will enable the party and its coalition partners to negotiate acceptable geographical and functional limits on the extent of collective self-defense; because of the increasing ability of the executive office under Koizumi's strong leadership to override CLB interpretations; and because the legislative bill will only require a simple majority in the Diet rather than the twothirds majority required for constitutional revision. ${ }^{28}$ The irony is that the LDP is looking to push through collective self-defense by revising article 9 but also mixed with a substantial amount of reinterpretation, thus employing the same sleight-ofhand tactics that have traditionally been anathema to the revisionists.

\section{Democratic Party of Japan}

The DPJ has experienced greater difficulty in developing an intra-party consensus on the form of revision and how to position itself as the main opposition party on this issue. It initiated its own Research Committee on the Constitution in 1999, which produced a final proposal in October 2005. The DPJ intends to produce its draft version of a new constitution in 2006. Its basic position is conceptualized as constitutional "augmentation" (soken). Influential figures from all wings of the party are disturbed by what they perceive as the hollowing out of the constitution's principles by endless government reinterpretations. Instead, the DPJ aims to reaugment the constitution's fundamental pacifist principles and clearly demarcate the use of military force for individual self-defense and in support of the United States, while at the same time expanding Japan's scope for international security cooperation with the wider East Asian regional community and the UN.

Internal factionalism has hindered consensus-building. The SDPJ rump led by Takahiro Yokomichi opposes revision in general and especially any moves to permit collective self-defense. Ichiro Ozawa has made common cause with Yokomichi on this position, arguing that constitutional revision is unnecessary for Japan to play an international security role. Ozawa and Yokomichi have jointly argued that Japan should avoid any move to constitutional revision that would only enable the LDP to further expand support for the United States, and that instead Japan should support the establishment of a UN standing army with JSDF participation. ${ }^{29}$ The social progressives in the party, led by the former DPJ President Naoto Kan, are more open to revision, but also propose establishing a special reserve force, separate from the JSDF, for overseas operations. ${ }^{30}$ They clearly intend to expand the scope for Japanese international security cooperation, but to do this in a means divorced from, and therefore capping the future potential extent of, JSDF deployment overseas in support of U.S. military operations.

\footnotetext{
27 “Jieitai o Dō Suru Kanzen Shimurēshon," AERA, August 5, 2004, p. 19.

${ }^{28}$ Samuels, Politics, Security Policy and Japan's Cabinet Legislation Bureau, pp. 7-12.

29 "Minshu Anzen Hosho no Kabe," Asabi Sbimbun, August 4, 2004, p. 4.

30 "DPJ Set to Submit Own Proposals on Constitution," Japan Times Online, January 14, 2004.
} 


\section{HUGHES}

On the other more liberal or conservative-leaning wings of the DPJ there is a greater appetite for constitutional revision and the possible exercise of collective self-defense. The former leader Yukio Hatoyama has advocated a limited form of collective self-defense. ${ }^{31}$ Another former leader Katsuya Okada caused controversy within the party when he argued in a speech in the United States in July 2004 that based on clear UN resolutions, Japan could actually use military force to contribute to international security, although this definition was closer to collective security. ${ }^{32}$ Seiji Maehara, succeeding Okada until his replacement by Ozawa in April 2006, has stated that Japan should investigate, based on constitutional revision, the exercise of collective self-defense and be entitled to use military force in carefully limited circumstances such as regional contingencies and in UN-led operations. ${ }^{33}$

The DPJ has had to forge compromises in its proposals for constitutional revision. In a similar fashion to the LDP, it first proposed in 2004 that the existence of the JSDF and right of individual self-defense should be recognized in the constitution. Its second proposal also focused on specifying an international security role for the JSDF, but linked it more closely to the concept of collective security and UN operations. ${ }^{34}$ The DPJ's third major proposal also resembled that of the LDP by seeking to create a Basic Security Law that would draw up specific restrictions on the international security operations of the JSDF. ${ }^{35}$

\section{Komeito}

Komeito's position in coalition governments with the LDP since 1999 provides it with considerable influence in this debate. The party produced its own points for debate in June 2004. Komeito's basic position, determined in large part by its pacifist grassroots supporters, is one of constitutional "supplementation" (kaken). It seeks to essentially preserve the current constitution, but to add new features addressing the changing domestic and international environment, and thus contrasts with the DPJ's plans for wholesale revision and expansion. Komeito has advocated retaining article 9 while recognizing the existence of the JSDF, the right of individual self-defense, and that the JSDF has an international security role. However, it has stated its opposition to any exercise of collective self-defense. 36

\section{Social Democratic Party of Japan, and Japan Communist Party}

In contrast to the other parties, the SDPJ, recoiling from its experience of coalition government in the 1990s, has returned to its position of outright opposition to any constitutional revision. In February 2006, the SDPJ reversed its 1994 recognition of the JSDF's constitutionality and sought to convert the 1967

31 "Minshu Riberarusei Kesshū," Asabi Sbimbun, February 8, 2006, p. 4.

${ }^{32}$ Katsuya Okada, "Atarashii Nihon to 21 seiki no Nichibei Kankei”, at www.dpj.or.jp.

33 "Maehara Backs Changing War-Renouncing Article 9," Japan Times Online, October 18, 2005.

34 "Minshu Riberarusei Kesshū," Asabi Shimbun, February 8, 2006, p. 4.

35 Minshutō Kempō Chosakai, Minshutō Kempō Teigen, October 31, 2005, pp. 15-16, at www.dpj.or.jp.

36 Kōmeitō, Kōmeitō Kempō Chōsakai ni Yoru Ronten Seiri, June 17, 2004, at www.komei.or.jp. 
Non-Nuclear Principles into binding law. It has been joined in its anti-revision stance by the Japan Communist Party. While declining support for both these parties in the Diet makes them unlikely to be able to influence the debate, they could hold the balance of power in any Diet vote.

\section{Convergence among diversity?}

Diet opinion is clearly in favor of some form of revision. In April 2005 the House of Representatives reported a consensus that article 9 should be revised to acknowledge Japan's right to self-defense and the constitutionality of the JSDF. ${ }^{37}$ However, the House of Councillors failed to agree on specific revisions, and neither house was able to reach a consensus on revisions relating to the exercise of collective self-defense (although they both agreed that Japan should engage more actively in international security cooperation). ${ }^{38}$

Japan's principal business association, the Keidanren, produced its own report in 2005 proposing the recognition of the JSDF and the exercise of collective self-defense. ${ }^{39}$ Yomiuri Shimbun, Japan's largest circulation newspaper, produced a draft constitution in 1994, urging the recognition of the JSDF and an international security role for Japan. The liberal magazine Sekai and newspaper Asabi Shimbun responded with their own proposals that advocated keeping article 9 intact but passing instead basic security laws that would provide an international security role for Japan, based on the creation of a special peace corps for non-combat humanitarian and developmental cooperation. Meanwhile, a number of civil society groups, including the Article 9 Association and Constitutional Pilgrimage Association, have intensified their opposition to constitutional revision.

According to a June 2004 poll, prior to the elections for the House of Councillors, 62 percent of all candidates favored constitutional revision. ${ }^{40}$ Another poll in July 2004 of 547 Diet members from both houses found that 64 percent favored specifying an international security role for the JSDF in a revised constitution and 55 percent favored collective self-defense. ${ }^{41}$

The public also appears to have tilted towards constitutional revision, with an Asabi Shimbun poll in May 2004 recording 53 percent of respondents in support of revision-the first time a majority was recorded since it began polling on the issue in 1995. Sixty percent of those polled still opposed revising article 9, but this was down 14 points from the last survey, in 2001.42 Another Asabi Shimbun poll in

37 “Kyujo Kaisei Rongi Zenshin," Yomiuri Sbimbun, April 1, 2005, p. 2.

38 Shugiin Kempo Chosakai Hokokusho, April 15, 2005, at www.shugiin.go.jp; Sangiin Kempo Chosakai Hokokusho, April 2005, at www.sangiin.go.jp.

39 Nihon Keizai Dantai Rengokai, Waga Kuni Kibon Mondai o Kangaeru: Kore Kara no Nibon o Tenbo Shite, January 18 2005, at www.keidanren.or.jp.

40 “62\% Running for Upper House Support Changing Constitution," Japan Times Online, June 21, 2004.

41 “Kaikenron wa Kokusai Koken Shiko ni," Ekonomisuto, Rinjizohan, July 12, 2004, pp. 4-5.

42 "Public Gradually More accepting of Constitutional Change," Japan Times Online, May 3, 2004. 


\section{HUGHES}

May 2006 recorded over sixty percent in favour of revision to recognise the JSDF, with around forty percent for designating it as a military and for the exercise of collective self-defense; and, most tellingly, over sixty percent of the population under sixty years old supported revision, reflecting the generational shift in attitudes towards revision. ${ }^{43}$

Hence, the parties and public alike increasingly accept the need for constitutional revision and agreement is beginning to converge on three focal issues: recognizing and the name of the JSDF as a military, defining the military's international security role, and, most thorny of all, collective self-defense. These three issues will likely be fought out both by constitutional revision and by passing supplementary legislation such as a Basic National Security Law to tackle those issues that are deemed too controversial to include in the constitution.

\section{Scenarios for Attempting Constitutional Revision and Outcomes}

1. Revision in line with the LDP model. The LDP's position as the governing party and the dominance of its revisionist elements means that it carries the initiative in any constitutional revision, and that its draft is likely to form the principal basis of any final draft put before the Diet and public. If the LDP follows its preferred twostage process of constitutional revision accompanied by Diet legislation and reinterpretation, it will come close to success in its principal objectives. A broad consensus for its innocuous looking proposals to recognize the Self-Defense Military and its international role already exists in the Diet. Even if the DPJ recognizes the real intent behind designating the JSDF a military as a means to create a bridgehead to collective self-defense in the second stage of Diet legislation, the LDP may still be able to take enough of the DPJ with it, especially the younger liberals and conservatives around Maehara. Komeito will resist, but probably capitulate in return for compensation on its domestic political agenda and to keep its place in the government, and has shown a readiness in the past to compromise over controversial security legislation as with the Regional Contingency Law and the Iraqi Reconstruction Law.

If the LDP can confine the initial debate to recognition of the JSDF and its international security role, it may then form the necessary consensus among its own members and with Komeito to take a readymade two-thirds majority in the House of Representatives, and take another 30 or so votes with it from the DPJ and other parties in the House of Councillors. The LDP would then turn to tackling collective self-defense through a Diet bill for a Basic National Security Law. It could maintain its own internal consensus and Komeito's support by building into the bill restrictions that limit the use of force to the East Asia region and exclusively in support of the United States, but then still manage to breach the ban on collective self-defense. It could also draw support from younger conservative elements of the DPJ grouped around Maehara, which have indicated that they intend to pursue the issue of collective self-defense through Diet legislation. Even if the LDP fails to

43 “Kaiken Nijimu Genko Shiko," Asabi Shimbun, May 3, 2006, p. 10. 
pass this legislation the first time around, it can always attempt this again later, when the controversy has abated, having already established the necessary constitutional principles to open the way for reinterpretation.

2. Revision to recognize de facto realities. The second scenario is that constitutional revision occurs by a similar process to above, recognizing de facto realities, but with no move to breach the ban on collective security by Diet legislation. This scenario could arise as a result of splits within the LDP or in its coalition with Komeito over fears that anything more than the recognition of current realities would open the floodgates for collective self-defense reinterpretation. It would also occur if the DPJ maintains its solidarity in both Houses and opposes anything other than the recognition of de facto realities. This is likely if Ozawa retains his grip on the party leadership, due to the fact that, unlike his predecessor Maehara, he has determined to practice adversarial politics and not to offer cooperation with the LDP on constitutional revision-shown by the DPJ's eventual decision to submit in May 2006 an independent bill for the constitutional referendum. Moreover, Ozawa may harbour hopes of drawing the Komeito away from the LDP coalition if he shows greater sympathy with their position on the constitution. However, as with the first scenario, de facto recognition will still leave open the door to the LDP to seek to breach the ban on collective self-defense by reverting at a later date to its old tactic of simple reinterpretation.

3. Non-revision. A final scenario is the failure of even revision attempts limited to recognizing de facto realities. It might prove simply too complex to forge intraparty LDP and LDP-Komeito consensus, compounded by strong opposition from the DPJ. This could be especially so when any draft revision is subject to prolonged Diet and public scrutiny. Or, LDP plans might yet be undermined by the bureaucracy. The CLB could reassert its dominance on constitutional issues once Koizumi, who has the popular mandate to govern assertively, retires from the premiership. ${ }^{44}$ It may also be that revision plans are dragged down by a range of controversies over other, non-security related issues involved in revision. The LDP might be banking on bundling the security measures together with measures on human rights as a means to smooth revision with the public. ${ }^{45}$ On the other hand, the LDP draft contains many controversial areas relating to patriotism, the position of the emperor, and the media which may incite political and public opposition. Lastly, achieving even the 50 percent hurdle of public approval in any case will be mightily difficult. Hence, the possibility of failure is real. But even in this instance it will not totally shut off the LDP's and government's options to push forward Japan's security role. They can always fall back on revision by reinterpretation, even if this method is providing diminishing returns.

\section{Implications for Japan's Security Policy and International Relations}

The scenarios presented above hold differing implications for Japan's military role, its U.S. alliance, and its role in UN-centered military operations. If the

\footnotetext{
${ }^{44}$ Samuels, Politics, Security Policy and Japan's Cabinet Legislation Bureau, pp. 7-8.

${ }^{45}$ Boyd and Samuels, Nine Lives?, p. 55.
} 


\section{HUGHES}

LDP plan is successful, Japan, with its right of collective self-defense established, will be able to engage in the full gamut of military operations, including its current participation in UN peacekeeping operations and in "coalitions of the willing" in Afghanistan and Iraq (Japan announcing in June 2006 its decision to "redeploy" the JSDF in Iraq, a euphemism for near total withdrawal), as well as an extension to partake in collective security and U.S.-led coalition operations. Although it may continue to limit collective self-defense to East Asia and in support of the United States, it will effectively become a "normal" military state.

If the second scenario, de facto recognition, is followed, this will enable Japan to continue to its current non-combat participation in UN and U.S. operations, and finally settle criticisms of these as unconstitutional, opening the way for its increased participation in these types of operations. However, Japanese policymakers will still be free to pursue the reinterpretation route to permit participation in a full range of operations. Thus revision in this form will be a way-station on Japan's path toward assuming a "normal" military role, rather than placing any kind of long-term cap on the remilitarization of its security policy.

The third scenario, non-revision, would certainly slow down and possibly even reverse the current direction of Japan's security policy. It would lead to the questioning of even current activities as against the spirit of the constitution and strengthen the constitution-preservation argument. It is less likely to halt participation in UN missions. Indeed, it may only temporarily slow Japan's military path. Faced with the same pressures to pursue an enhanced military path, Japan could resort to reinterpretation once again to push forward its military role, even if at an even slower pace.

Japan's developing military role will impact its key international relations in different ways. The LDP route would strengthen the U.S.-Japan alliance and provide new avenues for military cooperation, but the United States needs to be careful what it wishes for. While the LDP plan will create a more active ally, it will also release an ally from previous restrictions, conceivably empowering it to at last pursue a more independent security agenda from the United States.

In East Asia, clearly China and South Korea would be happier with the constitution continuing to bind Japan's military power, exercised either independently or through the mechanism of the U.S.-Japan alliance. The LDP plan may be very hard for Japan's Northeast Asian neighbors to live with. China has already criticized LDP plans, and in his independence anniversary speech in March 2006, President Roh Moo Hyun echoed this criticism. ${ }^{46}$ The result will be the further deterioration of already strained ties.

\section{Conclusion}

Japanese policymakers look set to move around yearend 2006 to begin to implement genuine attempts at constitutional revision. The changeover in power in 2006 from Koizumi to possible successors such as Abe, Fukuda, Aso or Tanigaki

46 “Roh Raps Constitutional Change," Japan Times Online, March 2, 2006. 
may impose a temporary slowdown on revision efforts. But the revision debate has decisive mid to longer term forward momentum due to the confluence of international and domestic pressures. The status quo in security is no longer tenable with the rise of new threats and alliance demands. In addition, the traditional practice of reinterpretation has for many reached its limits. Many policymakers believe the constitution has to be revised, both to provide greater flexibility and also clearer guidelines for Japan's security policy.

The major parties have reached a broad consensus on the importance of tackling three key issues: JSDF recognition, an international security role, and collective self-defense. The LDP as the governing party is seeking to push all three elements, via formal constitutional revision and Diet legislation involving reinterpretation. The LDP approach is the most likely scenario, provided that it can bring the Komeito and sections of the DPJ with it. However, simple de facto recognition of current realities or even non-revision are strong possibilities. Any of these scenarios will shape Japan's range of military options and relations with the United States and East Asia. Indeed, Japan's aspirations to assume the security identity of a "normal" state are very much at stake in the constitutional revision debate. ${ }^{47}$

${ }^{47}$ Christopher W. Hughes, Japan's Reemergence as a "Normal" Military Power (Oxford: Oxford University Press, 2004), pp. 9-19. 